\title{
Factors Influencing Selection of Resting Sites by Cattle on Shortgrass Steppe
}

\section{R.L. SENFT, L.R. RITTENHOUSE, AND R.G. WOODMANSEE}

\begin{abstract}
Spatial patterns of cattle resting behavior were investigated on shortgrass steppe. Resting was divided into daytime and nighttime categories. Sites selected for daytime resting during June through August were low-lying areas, fencelines, and stock-water area. Daytime resting during September through May occurred on south-facing slopes and lowland areas. Degree of use of warm slopes varied from month to month, peaking in midwinter. A significant portion of daytime resting occurred near water $(23 \%)$ and fencelines (27\%) at all times of the year. Resting at night during October through May occurred on south-facing slopes, low-lying areas, sites with sandy soils, and sites with high buffalo grass (Buchloe dactyloides) cover. During June through September, cattle preferred sites on east-facing slopes and on lowlands. Cattle rested near fencelines less at night than during the day. Patterns of and factors correlated to resting were different from those associated with grazing activity. Resting behavior was correlated with topographic variables, whereas previous work has shown grazing to be correlated with vegetation variables.
\end{abstract}

Long-term management strategies for grazing ecosystems should consider animal-landscape interactions. Research has traditionally emphasized livestock grazing and travel behavior (or an artifact such as forage utilization), while ignoring resting or bedding behavior. Distribution of resting is potentially important because sites selected for resting are often sites of nutrient accumulation (Hilder and Mottershead 1963, Gillingham and During 1973). Further, resting is a form of animal maintenance behavior (Arnold and Dudzinski 1978) which occupies up to $50 \%$ of activity time. For management purposes, it is important to know where resting activity occurs and the environmental factors that contribute to observed patterns.

Preliminary research suggested that cattle resting was correlated to abiotic factors, that there was a seasonality to resting distribution, and that factors influencing daytime and nighttime resting were fundamentally different (Senft et al. 1983). These inferences required further investigation bccause the study area was small ( 25

\footnotetext{
Authors are former graduate student and professor, Range Science Department. Colorado State University, Fort Collins 80523. Senft is currently at Animal, Dairy, and Veterinary Sciences Department, UMC 48, Utah State University, Logan 84322.

This project was funded in part by National Science Foundation Grant DEB7906009 and the Colorado State University Experiment Station Scientific Series Paper No. 2951 .

The authors thank the Central Plains Experimental Range, USDA-ARS, for their assistance and cooperation. The authors thank M.C. Shoop and W. Pinchak for their comments on an early draft of this manuscript.

Manuscript accepted December II, 1984.
}

ha) and uniform in terms of vegetation. Time scales used were variable. Work with grazing behavior has indicated that a shift of observational scale may result in the emergence of a new set of predictors (Senft et al. 1983, Senft et al. 1985). Thus, we were interested in 3 questions: are patterns observed on small, uniform pastures a pplicable to larger, heterogenous areas; does seasonality of cattle resting patterns shift abruptly or gradually; and finally, do patterns of and factors correlated to resting compare with those of grazing?

This paper describes cattle resting behavior on shortgrass steppe in northeastern Colorado. The objectives of this research were to: (1) document spatial patterns of resting behavior on shortgrass range, (2) determine relationships between observed patterns and environmental factors, and (3) build predictive regression models of resting activity.

\section{Methods}

\section{The Study Area}

Research was conducted on the USDA-ARS Central Plains Experimental Range (CPER) in northeastern Colorado. The semiarid climate of CPER has been described in detail elsewhere (Jameson 1969). Mean maximum monthly temperatures for January and July are 0.5 and $28^{\circ} \mathrm{C}$, respectively. Mean minimum monthly temperatures for January and July are -12 and $12^{\circ} \mathrm{C}$. Average annual precipitation is approximately $310 \mathrm{~mm}$, with considerable year-to-year variation.

Vegetation is shortgrass steppe, dominated by blue grama [Bouteluoa gracilis (H.B.K.) Lag.] and buffalo grass [Buchloe dactyloides (Nutt.) Engelm]. There is little or no shade or shelter for large animals. Terrain is characterized by gently rolling hills and intermittent drainages. Relief is approximately $25 \mathrm{~m}$. Closed basins, or playas, are common. Plant communities are described elsewhere (Senft et al. 1985).

Cattle resting behavior was studied on a 125 -ha pasture (Fig. 1). Topographic features include a ridge running diagonally across the center from northwest to southeast, 2 intermittent drainages lying parallel to the ridge, and a playa lying southeast of the center of the pasture. A grazing exclosure is located in the center of the pasture, and a stock-watering tank and salt block are in the center of the north fenceline (asterisk in Fig. 1). Seven to 11 yearling heifers freely roamed the study pasture. Herd size was adjusted seasonally to maintain light to moderate stocking, based on available forage. 
a)

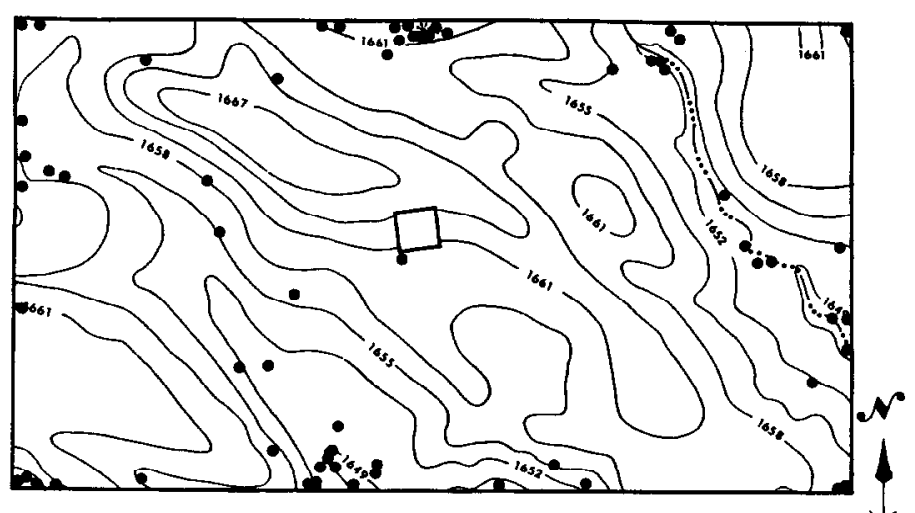

b)

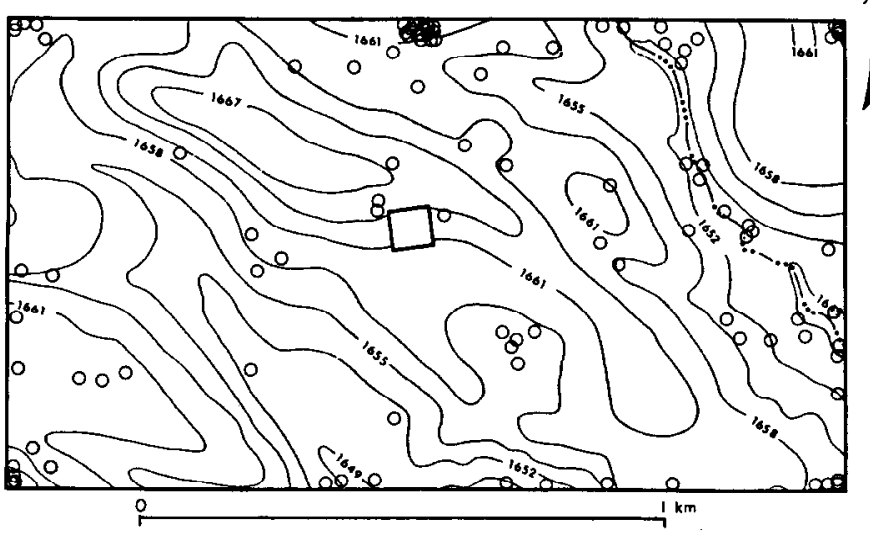

Fig. 1. Resting sites selected by cattle during daylight: (A) warm season (June through August); (B) cool-season (September through May). Three-m (10-fi) contour intervals are shown. Location of the water tank is indicated by an asterisk (*).

\section{Behavior Observations and Analysis}

Resting behavior was defined as any stationary, nonfeedin activity engaged in by the herd for 30 minutes or longer (e.g standing, lying, ruminating, sleeping, and social activity). Restin was divided into daytime- and nighttime-resting categories. Res ing behavior was observed for 1 week each month over a 2-ye: period (June 1980 through May 1982). Locations of resting sits were recorded on topographic maps.

To determine which factors influenced resting distribution, da1 werc analyzed using multiple regression techniques (Senft et a 1983). Maps of the study area were gridded into 0.1-ha cells. Tot: resting time (h) was summed in each cell for daytime and nighttim categories. Resting time per month was the dependent variable $i$ the analysis. A pool of potential independent variables included topographic factors, frequencies of 22 plant species, and percer tage cover of the dominant perennial grasses. Values for topogr: phic factors were estimated from an enlarged topographic ma (Fig. 1). Values for vegetation cover and frequency were obtaine from surveys conducted during the US/IBP Grassland Biom Study. Predictors of spatial behavior were selected according 1 the criteria of Senft et al. (1983).

We hypothesized that, on shortgrass steppe, microclimats would be associated with major topographic features or terrai types. Accordingly, the study area was divided into six zones; ( ridgetops, (2) south-facing slopes, (3) north-facing slopes, (4) lov lands and bottoms, (5) fencelines and fence corners, and (6) th watering area. The watering area was defined as the zone within $100-\mathrm{m}$ radius of the water tank (asterisk in Fig. 1). The fencelin zone included any site within $25 \mathrm{~m}$ of a fence or fence corne Ridgetops included sites above the 1,660-m contour line wit slopes less than $5 \%$. The lowlands and bottoms categories cor sisted of lower parts of drainage areas, toeslopes, and low-lyin, level areas. North-and south-facing slope categories included sitt on northern or southern slopes, respectively, not included in any the other 4 categories. The smallest area considered a potenti resting site was the 0.1 -ha grid cell used for mapping and statistica analysis.

Table 1. Breakdown of monthly observed daytime resting by topographic zone (percent of total resting time).

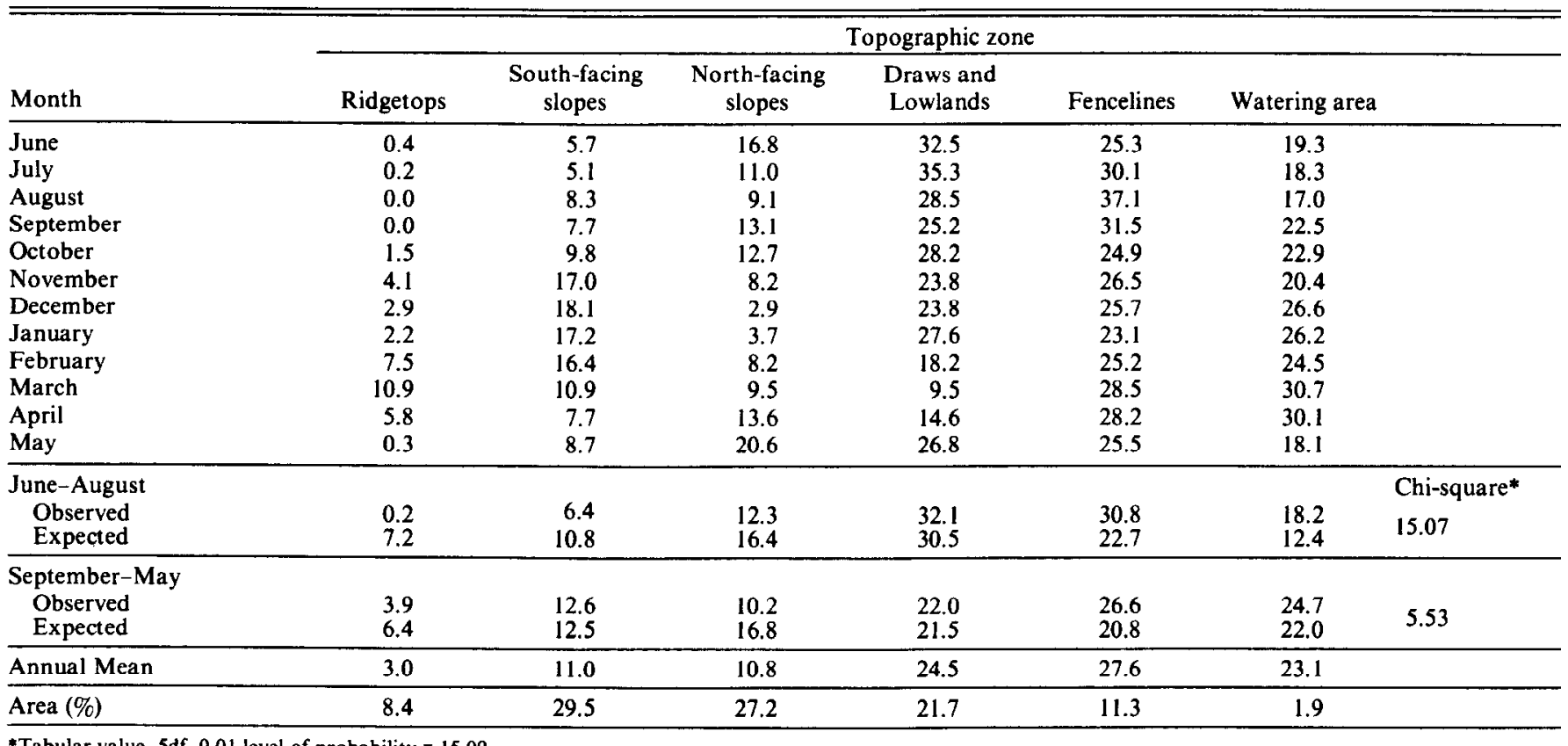




\section{Results}

\section{Patterns of Daytime Resting}

Locations of observed resting sites are shown in Figure 2. Between 18 and $25 \%$ of resting occurred near the stock-watering facility at all times of the year (Table 1). Cattle moved to water in midmorning and frequently remained in the watering area for several hours. Fencelines also received a disproportionate amount of daytime-resting activity, much of which was concentrated in fence corners (Fig. 1).

Daytime use of south-facing slopes peaked in winter, while use of north-facing slopes peaked during summer (Table 1). During summer, cattle spent a substantial portion of the daylight hours standing near, and wallowing in, intermittent ponds. Cattle generally preferred low-lying areas with gentle slopes and avoided upper slopes.

Spatial patterns of daytime resting were described by proximity to the water tank ( $1 /$ distance), proximity to fence corners, elevation, and aspect (Table 2). The elevation term was expressed as 1.0 divided by elevation $(\mathrm{m})$ above the lowest point in the pasture. The aspect term was expressed as cosine of degrees deviation from due south. The coefficient of the aspect term was a sinusoidal function of time, peaking in January. The time-varying aspect coefficient resulted from seasonal shifts in preference for north- and southfacing slopes. During the warm scason (Junc through August), the aspect term dropped out of the model and the coefficient of the elevation term more than doubled (Table 2). The value of the elevation coefficient was greatest during July.

For behaviors that occur in discrete locations in space, regression models, when used as predictive devices, generate probability distributions of behavior (Senft et al. 1983). Seasonal differences in patterns of daytime resting behavior were reflected in model predictions (Fig. 2). The predicted pattern of summer daytime resting emphasized low-lying sites and the stock-watering facility, excluding a large portion of the study area. During cool-season months, however, a larger array of sites were likely to be used. Predicted patterns of resting were not significantly different $(p<, 01)$ than observed (Table 1).

\section{Patterns of Nighttime Resting}

Locations of bedding sites are shown in Figure 3a. Patterns of bedding were very similar throughout the year (Table 2). Use was primarily in the low-lying areas of the pasture, especially on channels of intermittent drainages and on lower slopes; no bedding sites were observed on ridgetops. Some bedding occurred along fencelines, particularly in corners; but the amount of fenceline use was less at night than during daylight hours.

To isolate the influence of aspect on bedding-site selection, we divided the study area into 4 zones, each centered on a different cardinal direction (Table 4). From October through May (the cool season), an average of $60 \%$ of all nighttime resting occurred on a)

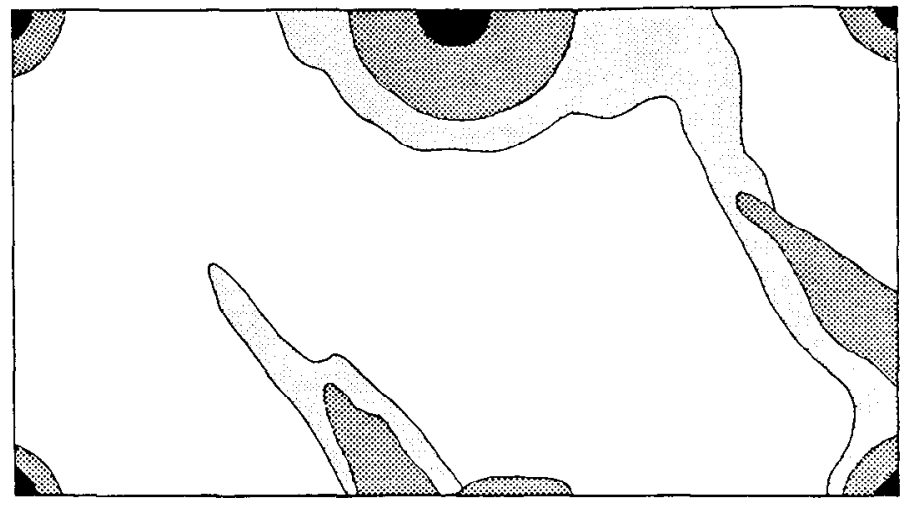

b)

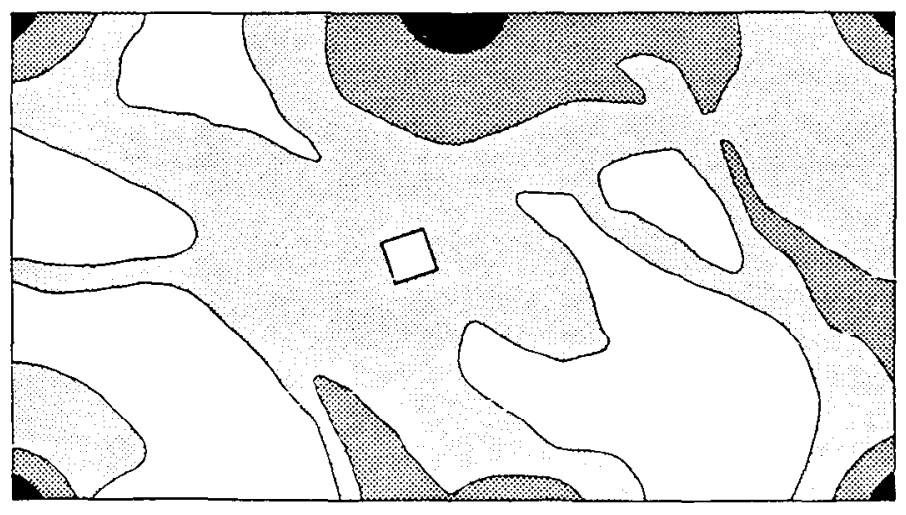

hours $\cdot$ hectare ${ }^{-1} \cdot$ month $^{-1}$

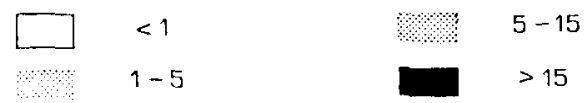

Fig. 2. Probability distributions of daytime resting generated by seasonal regression models. (A) Warm season. (B) cool season.

south-facing slopes. During the remaining 4 months of the year (the warm season), $48 \%$ of bed ding activity occurred on east-facing slopes and only $30 \%$ on south-facing slopes.

Six independent variables were required to describe spatial patterns of nighttime resting (Table 5). These were: proximity to fence corners, percent slope, aspect ( 2 seasonal variables), frequency of a soil texture indicator, spreading buckwheat (Erigonum effusum

Table 2. Coefficients in the seasonal daytime resting models.

\begin{tabular}{|c|c|c|c|c|c|c|}
\hline \multirow[b]{2}{*}{ Season } & \multicolumn{6}{|c|}{ Independent variable } \\
\hline & $\begin{array}{l}\text { Proximity } \\
\text { to water }\end{array}$ & $\begin{array}{l}\text { Proximity to fence } \\
\text { corners }\end{array}$ & Elevation & Aspect & Constant & $r$ \\
\hline $\begin{array}{c}\text { Warm } \\
\text { (June-Aug) }\end{array}$ & 416.45 & 157.71 & 11.25 & - & -1.89 & .426 \\
\hline $\begin{array}{c}\text { Cool } \\
\text { (Sept-May) }\end{array}$ & 408.80 & 106.60 & 5.34 & $\mathbf{k}_{4}$ & -1.51 & .555 \\
\hline $\begin{array}{l}\text { Mathematical } \\
\text { expression in model* }\end{array}$ & $\frac{1}{x_{1}}$ & $\frac{1}{x_{2}}$ & $\frac{1}{x_{3}}$ & $\cos \left(x_{4}\right)$ & c & \\
\hline
\end{tabular}

${ }^{*} \mathrm{x}_{1}=$ distance from stock tank (meters)

$\mathrm{x}_{2}=$ distance from nearest fence corner (meters)

$\mathrm{x}_{3}=$ elevation above $1646 \mathrm{~m}$ contour (meters)

$\mathrm{k}_{4}=0.600(\cos (0.5236($ month -12$))$

$\mathrm{x}_{4}=$ degrees deviation from due south 
a)

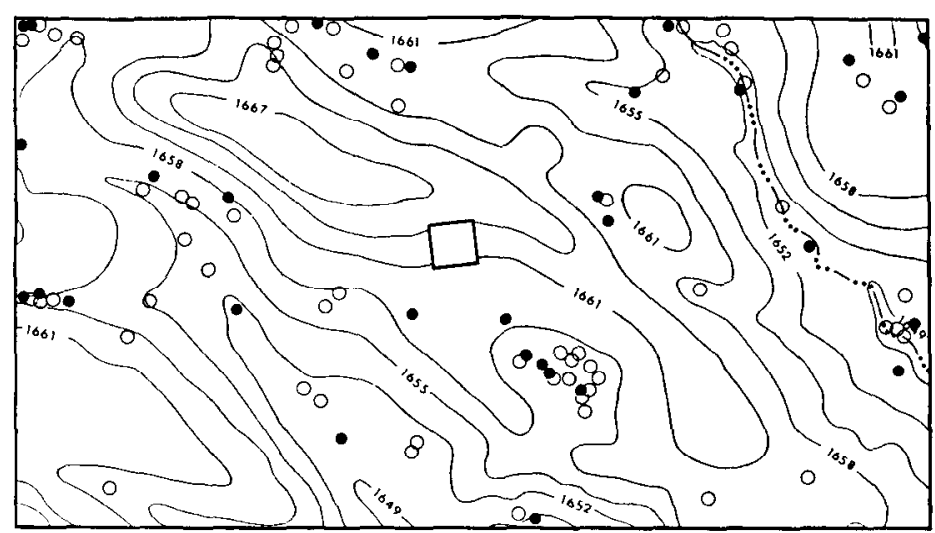

b)

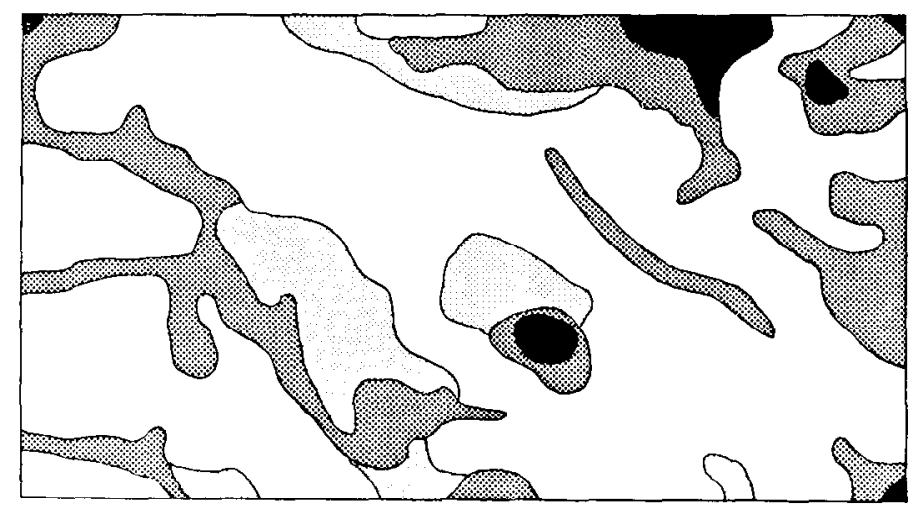

hours $\cdot$ hectare ${ }^{-1} \cdot$ month $^{-1}$

$$
\begin{aligned}
& <1 \quad \text { अे } 5-15 \\
& 1-5>15
\end{aligned}
$$

Fig. 3. (A) Resting sites selected at night: warm season (June through September) sites are indicated by solid dots; cool-season (October through May by open circles. (B) Probability distribution of resting at night.

\begin{tabular}{|c|c|c|c|c|c|c|c|}
\hline \multirow[b]{2}{*}{ Month } & \multicolumn{6}{|c|}{ Topographic zone } & \\
\hline & Ridgetops & $\begin{array}{l}\text { South-facing } \\
\text { slopes }\end{array}$ & $\begin{array}{c}\begin{array}{c}\text { North-facing } \\
\text { slopes }\end{array} \\
\end{array}$ & $\begin{array}{l}\text { Draws and } \\
\text { lowlands }\end{array}$ & Fencelines & \multicolumn{2}{|l|}{ Watering area } \\
\hline June & 0.0 & 46.4 & 14.3 & 10.7 & 28.6 & 0.0 & \\
\hline July & 0.0 & 31.4 & 17.2 & 20.0 & 31.4 & 0.0 & \\
\hline August & 0.0 & 31.4 & 22.9 & 25.7 & 20.0 & 0.0 & \\
\hline September & 0.0 & 16.7 & 31.3 & 35.4 & 8.3 & 8.3 & \\
\hline October & 0.0 & 13.3 & 31.7 & 35.0 & 5.0 & 15.0 & \\
\hline November & 0.0 & 24,4 & 29.3 & 26.8 & 4.9 & 14.6 & \\
\hline December & 0.0 & 45.5 & 12.1 & 15.2 & 15.1 & 12.1 & \\
\hline January & 0.0 & 45.0 & 7.5 & 15.0 & 17.5 & 15.0 & \\
\hline February & 0.0 & 38.7 & 16.1 & 25.8 & 9.7 & 9.7 & \\
\hline March & 0.0 & 37.5 & 20.8 & 41.7 & 0.0 & 0.0 & \\
\hline April & 0.0 & 57.9 & 10.5 & 31.6 & 0.0 & 0.0 & \\
\hline May & 0.0 & 77.8 & 5.6 & 5.6 & 11.0 & 0.0 & \\
\hline June-September & & & & & & & Chi-square \\
\hline Observed & 0.0 & 31.5 & 21.4 & 23.0 & 22.0 & 2.1 & 11.38 \\
\hline Expected & 0.0 & 32.7 & 15.0 & 34.5 & 14.9 & 2.9 & 11.50 \\
\hline \multicolumn{8}{|l|}{ October-May } \\
\hline Observed & 0.0 & 42.5 & 16.7 & 24.6 & 17.9 & 8.3 & \\
\hline Expected & 0.0 & 32.7 & 15.0 & 34.5 & 14.9 & 2.9 & 19.31 \\
\hline Annual Mean & 0.0 & 38.8 & 18.4 & 24.0 & 12.6 & 6.2 & \\
\hline Area $(\%)$ & 8.4 & 29.5 & 27.2 & 21.7 & 11.3 & 1.9 & \\
\hline
\end{tabular}

Table 3. Breakdown of monthly observed nighttime resting (bedding) time by topographic zone (percent of total resting time).
Table 4. Breakdown of observed monthly nighttime resting time by aspect (percent of total resting time)

\begin{tabular}{lcccc}
\hline & \multicolumn{4}{c}{ Exposure } \\
\cline { 2 - 5 } Month & $\begin{array}{c}\text { North- } \\
\text { facing }\end{array}$ & $\begin{array}{c}\text { East- } \\
\text { facing }\end{array}$ & $\begin{array}{c}\text { South- } \\
\text { facing }\end{array}$ & $\begin{array}{c}\text { West- } \\
\text { facing }\end{array}$ \\
\hline $\begin{array}{l}\text { June through } \\
\text { September Mean }\end{array}$ & 8.9 & 48.1 & 30.0 & 13.0 \\
\hline $\begin{array}{l}\text { October through } \\
\text { May Mean }\end{array}$ & 8.9 & 23.5 & 59.6 & 8.0 \\
\hline Annual Mean & 8.9 & 31.7 & 49.7 & 9.7 \\
\hline Area (\%) & 29.2 & 26.6 & 36.2 & 8.0 \\
\hline
\end{tabular}

Nutt., or Eref), and percent buffalo grass cover. Each predictor had a time-varying coefficient, suggesting seasonal shifts in the tactics of site selection. The predicted annual pattern of nighttime resting is shown in Figure 3b. (Resting patterns predicted by cool-and warm-season models were combined, as the differences in seasonal patterns were not pronounced).

Predicted and observed seasonal bedding breakdowns are shown in Table 3. The chi-square value for the cool-season model was the result of over- or underprediction of behavior time for relatively small areas. The cool-season model underpredicted use of the watering area and overpredicted use of fencelines. Predicted cool-season use was accurate for the remaining $90 \%$ of the study area.

\section{Discussion}

\section{Relation to Grazing Patterns}

Distribution of resting differed from distribution of cattle grazing. While resting was primarily correlated to topographic variables, cattle selected grazing areas on the basis of relative forage abundance (Senft et al. 1985). Drainage channels and adjacent plant communities were preferred during the growing season (April through October); upland plant communitics werc preferred during the dormant season. A wide zone around the watering area received concentrated grazing and resting in all 
seasons, but a fouled zone immediately surrounding the water tank (radius $=60 \mathrm{~m}$ ) was not grazed. Cattle displayed no measurable preference for grazing fencelines or fence corners.

Grazing and resting patterns were partially dependent. Midnight grazing invaribly occurred in the immediate vicinity of bedding sites. During the course of the night, the resting site often "drifted" as cattle got up, grazed, and selected new bedding sites a short distance away. During the daylight hours, however, cattle walked to and from resting sites. Searching for desirable resting sites was especially evident in the interval between the late afternoon grazing period and bedding. Cattle traveled more while grazing during this period than at any other time of day.

\section{Resting and Comfort Seeking}

Behavioral thermoregulation may have been one of many factors influencing selection of resting sites. Since shade and shelter were absent from the study area, cattle would have to exploit micro-climates associated with topography. Our results indicated daytime use of cool exposures during summer and warm exposures during winter. Cattle may have selected nighttime resting sites on the basis of surface heat exchange properties. Spreading buckwheat, for examplc, is an indicator of sandy soils, which lose heat more rapidly than fine-textured soils. Buffalo grass mats, which were highly preferred during winter, may have been used for insulation against cold soil. Other aspects of comfort- seeking behavior are use of (or escape from) wind and escape from insect harassment. Summer use of slopes may have been related to wind (Weaver and Tomanek 1951). The only sites not affected by wind were sink holes. Cattle were observed resting in these holes on cold, windy days.

\section{Literature Cited}

Arnold, G.W., and M.L. Dudzinski. 1978. Ethology of free-ranging domestic animals. Elsevier Sci. Publ. Co., New York.

Gillingham, A.G., and C. During. 1973. Pasture production and transfer of fertility within a longestablished hill pasture. N.Z. J. Exp. Agr. 1:227-232.

Hilder, E.J., and B.E. Mottershead. 1963. The redistribution of plant nutrients through free-grazing sheep. Austr. J. Sci. 26:88-89.

Jameson, D.A. 1969. General description of the Pawnee Site. US/IBP Grassland Biome Tech. Rep. No. 1. Colorado State Univ., Fort Collins.

Senft, R.L., L.R. Rittenhouse, and R.G. Woodmansee. 1983. The use of regression models to predict spatial patterns of cattle behavior. J. Range Manage. 36:553-557.

Senft, R.L., L.R. Rittenhouse, and R.G. Woodmansee. 1985. Factors influencing patterns of cattle grazing behavior on shortgrass steppe. J. Range Manage. 38:82-87.

Weaver, J.E., and G.W. Tomanek. 1951. Ecological studies in a midwestern range: The vegetation and effects of cattle on its composition and distribution. Nebr. Conserv. Bull. No. 31. 